\title{
Perforin-secreting Killer Cell Infiltration and Expression of a 65-kD Heat-Shock Protein in Aortic Tissue of Patients with Takayasu's Arteritis
}

\author{
Yoshinori Seko, "81 Seiji Minota, " Akemi Kawasaki," Yoichi Shinkai," Keiko Maeda," Hideo Yagita," Ko Okumura," \\ Osamu Sato, ${ }^{\star}$ Atsuhiko Takagi, ${ }^{*}$ Yusuke Tada, ${ }^{*}$ and Yoshio Yazaki * \\ *Third Department of Internal Medicine, and ${ }^{\ddagger}$ Second Department of Surgery, Faculty of Medicine, University of Tokyo, Tokyo 113, \\ ${ }^{\S}$ Department of Immunology, School of Medicine, Juntendo University, Tokyo 113, and 'Institute for Adult Diseases, Asahi Life \\ Foundation, Tokyo 160, Japan
}

\begin{abstract}
Cell-mediated autoimmunity has been strongly implicated in the pathogenesis of vascular cell injury in Takayasu's arteritis. To clarify the immunological mechanisms involved, we examined the expression of a cytolytic factor, perforin in infiltrating cells of aortic tissue samples from seven patients with Takayasu's arteritis. We also examined the expression of a 65-kD heat-shock protein (HSP-65), human leukocyte antigen classes I and II, and intercellular adhesion molecule-1 in the aortic tissue. Immunohistochemical studies showed that the infiltrating cells mainly consisted of $\gamma \delta \mathrm{T}$ lymphocytes, natural killer cells, macrophages, cytotoxic $T$ lymphocytes and $T$ helper cells, and that perforin was expressed in $\gamma \delta \mathrm{T}$ lymphocytes, natural killer cells, and cytotoxic $T$ lymphocytes. In situ hybridization analysis also revealed expression of perforin mRNA in the infiltrating cells. Immunoelectron microscopic studies demonstrated that the infiltrating cells released massive amounts of perforin directly onto the surface of arterial vascular cells. We also found that expression of HSP-65, human leukocyte antigen classes I and II, and intercellular adhesion molecule-1 was strongly induced in the aortic tissue and might facilitate the recognition, adhesion and cytotoxicity of the infiltrating killer lymphocytes. These findings provide the first direct evidence that the infiltrating cells in the aortic tissue mainly consist of killer cells, and strongly suggest that these killer cells, especially $\gamma \delta$ T lymphocytes, may recognize HSP65 and play a critical role in the vascular cell injury of Takayasu's arteritis by releasing perforin. (J. Clin. Invest. 1994. 93:750-758.) Key words: natural killer cells $\bullet$ cytotoxic $T$ lymphocytes • $\gamma \delta \mathrm{T}$ lymphocytes $\bullet$ human leukocyte antigen • intercellular adhesion molecule-1
\end{abstract}

\section{Introduction}

Takayasu's arteritis is a form of vasculitis characterized by stenotic and occasionally dilated lesions in the aorta, its main branches, and the pulmonary arteries. A strong predilection for women and a high incidence in Asian and South American countries suggests a role for genetic factors. Several studies (13 ) have demonstrated an association between the disease and

Address correspondence to Yoshinori Seko, M.D., Third Department of Internal Medicine, Faculty of Medicine, University of Tokyo, 7-3-1 Hongo, Bunkyo-ku, Tokyo 113, Japan.

Received for publication 4 May 1993 and in revised form 8 September 1993.

J. Clin. Invest.

(c) The American Society for Clinical Investigation, Inc.

0021-9738/94/02/0750/08 \$2.00

Volume 93, February 1994, 750-758 specific human leukocyte antigen (HLA) ${ }^{1}$ types supporting immunopathological mechanisms. Histological findings of inflammatory cell infiltration and necrosis of the arterial vascular cells strongly suggest that cell-mediated autoimmunity plays an important role in the pathogenesis involved (4). The mechanism of vascular cell injury, as well as the primary cause that triggers the autoimmune process, are of great clinical significance and remain to be clarified. Natural killer (NK) cells and cytotoxic T lymphocytes (CTLs) play major roles in cell-mediated cytotoxicity, and are thought to kill virus-infected cells or tumor cells with effector molecules contained in their cytoplasmic granules. One of these effector proteins is named poreforming protein or perforin (5). Recent studies (6-12) have demonstrated that perforin is expressed by infiltrating lymphocytes in various diseases, as well as lymphocytes under physiological conditions, and can be a good marker for killer cells.

$\mathrm{T}$ lymphocytes are known to recognize antigens by their receptors in association with syngeneic MHC antigens, such as HLAs, on the surface of antigen-presenting cells. To become target cells for $T$ lymphocytes, the antigen-presenting cells must express MHC antigens. Furthermore, cell-cell interactions in the immune response are thought to be mediated by cell adhesion molecules expressed on both the immune cell and target cell. Intercellular adhesion molecule-1 (ICAM-1), which is a ligand for lymphocyte function-associated antigen-1, is thought to be induced by cytokines on various target cells at the site of inflammation, and to play an important role in the recognition, adhesion, and cytotoxicity of killer lymphocytes (13-17).

Heat-shock proteins (HSPs) are known to be synthesized by various cells in response to environmental stresses, such as temperature changes, inflammation, and viral infection. Evidence has accumulated that $\gamma \delta \mathrm{T}$ lymphocytes can recognize autologous HSPs and may play an important role in autoimmunity $(18,19)$.

In this study, we attempted to clarify the immunological mechanisms involved in the vascular cell injury of Takayasu's arteritis. We analyzed the phenotypes of the infiltrating cells and examined the expression of perforin by immunohistochemistry, immunoelectron microscopy, and in situ hybridization. We also examined the expression of a 65-kD HSP (HSP65 ), HLA classes I and II, and ICAM- 1 in the aortic tissue. We demonstrate synthesis and release of perforin by the infiltrating $\gamma \delta$ T lymphocytes, NK cells, and CTLs, leading to direct vascular cell damage. We also found enhanced expression of HSP65 , HLA classes I and II, along with ICAM-1 in the aortic

1. Abbreviations used in this paper: CTLs, cytotoxic T lymphocytes; HLA, human leukocyte antigen; HSPs, heat-shock proteins; HSP-65, 65-kD HSP; ICAM-1, intercellular adhesion molecule-1; NK, natural killer cells; TCR, T cell receptor. 
tissue, which particularly indicates a role for $\gamma \delta \mathrm{T}$ lymphocytes in the vascular cell injury of Takayasu's arteritis.

\section{Methods}

Patients. Aortic tissue samples were obtained at bypass surgery from seven patients (three male and four female, average age $=41.9 \mathrm{yr}$ ), in whom a clinical diagnosis of Takayasu's arteritis had been previously determined by angiography and blood analyses. For comparison with typical forms of atherosclerotic tissue, aortic tissue samples were also obtained at bypass surgery from four patients (three male and one female, average age $=69.3 \mathrm{yr}$ ) with an abdominal or thoracic aortic aneurysm.

Antibodies. Mouse anti-human CD4 (hybridoma Leu-3a), CD8 (Leu-2a), CD14 (Leu-M3), and CD20 (Leu-16) mAbs were purchased from Becton Dickinson Immunocytometry Systems (San Jose, CA). Mouse anti-human CD16 (3G8) and T cell receptor (TCR) $\gamma \delta$ (Identi-T TCR $\delta 1$ ) mAbs were purchased from Immunotech (Marseille, Cedex, France) and T Cell Sciences, Inc. (Cambridge, MA), respectively. The procedures for preparing a rat anti-mouse perforin (P1-8) mAb, which was also shown to react with human perforin, have been previously described (10). Briefly, rats were immunized with a polypeptide fragment of recombinant mouse perforin, which was prepared by transfecting a mouse perforin cDNA (20) fragment into Escherichia coli. The hybridomas with supernatant that exhibited reactivity to the recombinant mouse perforin fragment in ELISA were then cloned. The specificity of these $\mathrm{mAbs}$ for natural mouse perforin purified from an NK-like cell line was examined by immunoblot analysis and ELISA, and the mAb of clone P1-8 was selected for use in this study. We have confirmed in a previous study (21) that the cytoplasmic granules of a mast cell line transfected with mouse perforin cDNA are clearly recognized by this $\mathrm{mAb}$.

Mouse anti-HLA class I (W6/32) and rat anti-HLA class II (YE2/ 36HLK) mAbs were purchased from Dakopatts (Glostrup, Denmark) and Serotec Ltd. (Oxford, England), respectively. A mouse anti-human ICAM-1 (RR1/1) mAb was a gift from Dr. T. A. Springer (Harvard Medical School, Boston, MA).

A rabbit anti-human HSP- 65 polyclonal antibody was produced by immunizing rabbits with purified recombinant mycobacterial HSP-65, provided by Drs. van Embden and van der Zee (National Institute of Public Health and Environment Protection, Bilthoven, The Netherlands). This antibody reacted with only a $58-\mathrm{kD}$ protein in immunoblotting when nonionic detergent lysates of human lymphocytes were used as antigens (data not shown). This $58-\mathrm{kD}$ protein is the human homologue of mycobacterial HSP-65.

Immunoperoxidase. Freshly dissected aortic tissue samples were frozen in liquid nitrogen. Cryostat sections ( $6 \mu \mathrm{m}$ thick) were prepared, air dried, fixed in acetone for $5 \mathrm{~min}$, and incubated with mouse antihuman CD4, CD8, CD14, CD16, CD20, TCR $\gamma \delta$, HLA class I, ICAM$1 \mathrm{mAbs}$, or rat anti-HLA class II $\mathrm{mAbs}$ for $1 \mathrm{~h}$ at $37^{\circ} \mathrm{C}$. After washing in PBS, the sections were incubated with biotinylated anti-mouse IgG or anti-rat IgG (Vector Laboratories, Inc., Burlingame, CA) for $1 \mathrm{~h}$ at $37^{\circ} \mathrm{C}$. After washing in PBS, the sections were incubated with avidinbiotinylated immunoperoxidase complex ( $\mathrm{ABC}$-Immunoperoxidase Kit; Vector Laboratories, Inc.), according to the manufacturer's instructions; for $30 \mathrm{~min}$ at $37^{\circ} \mathrm{C}$ and washed in PBS, followed by reaction with diaminobenzidine tetrahydrochloride $(0.2 \mathrm{mg} / \mathrm{ml})$. After washing in PBS, the sections were counterstained with hematoxylin, dehydrated in ethanol, and the coverslips were mounted in xylene with resin. Aortic tissue samples from normal subjects were also stained for HLA classes I and class II and ICAM-1 as a control.

Immunofluorescence. Cryostat sections of aortic tissue samples were fixed in acetone and incubated with anti-HSP-65 antibody for $1 \mathrm{~h}$ at $37^{\circ} \mathrm{C}$. After washing, the sections were incubated with biotinylated anti-rabbit IgG (United Biomedical, Inc., Lake Success, NY) for $1 \mathrm{~h}$ at $37^{\circ} \mathrm{C}$, washed, and incubated with FITC-conjugated avidin D (Vector Laboratories, Inc.) for $30 \mathrm{~min}$ at $37^{\circ} \mathrm{C}$. The coverslips were then mounted with glycerin. Aortic tissue samples from normal subjects were also examined as a control.

Immunohistochemistry. Double-staining was performed for surface markers and perforin by an enzyme antibody method. Cryostat sections of aortic tissue samples were fixed in acetone for $5 \mathrm{~min}$, then incubated with mouse anti-human CD8, CD16, or TCR $\gamma \delta$ for $1 \mathrm{~h}$ at $37^{\circ} \mathrm{C}$. After washing in PBS, they were incubated with biotinylated anti-mouse IgG (Vector Laboratories, Inc.) for $1 \mathrm{~h}$ at $37^{\circ} \mathrm{C}$, washed in $\mathrm{PBS}$, and then incubated with avidin-biotinylated peroxidase complex (ABC-Immunoperoxidase Kit; Vector Laboratories, Inc.) for $30 \mathrm{~min}$ at $37^{\circ} \mathrm{C}$. After washing in Tris- $\mathrm{HCl}$ buffer, they were reacted with diaminobenzidine tetrahydrochloride $(0.2 \mathrm{mg} / \mathrm{ml})$ in Tris- $\mathrm{HCl}$ buffer, and the sections were fixed again in 4\% paraformaldehyde for $1 \mathrm{~min}$ and $0.5 \%$ periodic acid for $10 \mathrm{~min}$ at room temperature. To quench cross reaction of biotinylated anti-mouse IgG with rat anti-human perforin $\mathrm{mAb}$, the sections were blocked with mouse sera for $30 \mathrm{~min}$ at $37^{\circ} \mathrm{C}$, then incubated with rat anti-mouse perforin $\mathrm{mAb}$ for $1 \mathrm{~h}$ at $37^{\circ} \mathrm{C}$. After washing in PBS, the sections were incubated with biotinylated anti-rat IgG (Cappel Laboratories, West Chester, PA), which had been preabsorbed with mouse sera, for $1 \mathrm{~h}$ at $37^{\circ} \mathrm{C}$. After washing in PBS, the sections were incubated with avidin-biotinylated alkaline phosphatase complex (ABC-AP Kit; Vector Laboratories, Inc., according to the manufacturer's instructions) for $30 \mathrm{~min}$ at $37^{\circ} \mathrm{C}$. After washing in PBS, a substrate that generates a blue reaction product (Alkaline Phosphatase Substrate Kit III; Vector Laboratories, Inc.) was added, and then coverslips were mounted with resin without counterstaining.

Immunoelectron microscopy. Cryostat sections of aortic tissue samples were fixed in acetone for $3 \mathrm{~min}$ at $4^{\circ} \mathrm{C}$, and fixed in $4 \%$ paraformaldehyde in PBS for 1 min at room temperature. After washing in PBS, the sections were treated with $0.5 \%$ periodic acid for $10 \mathrm{~min}$ at room temperature. After washing in PBS, the sections were blocked with $2 \%$ rabbit serum in $\mathrm{PBS}$ for $30 \mathrm{~min}$ at $37^{\circ} \mathrm{C}$, then incubated with rat antiperforin $\mathrm{mAb}$ for $1 \mathrm{~h}$ at $37^{\circ} \mathrm{C}$, washed in PBS, and incubated with biotinylated rabbit anti-rat IgG antibody (Cappel Laboratories) for $1 \mathrm{~h}$ at $37^{\circ} \mathrm{C}$. After washing in PBS, the sections were incubated with avidinbiotinylated peroxidase complex (ABC-Immunoperoxidase Kit; Vector Laboratories, Inc.) for $30 \mathrm{~min}$ at $37^{\circ} \mathrm{C}$, washed in PBS, then fixed with $1 \%$ glutaraldehyde in PBS for $5 \mathrm{~min}$ at room temperature. The sections were washed in Tris- $\mathrm{HCl}$ buffer, and reacted with diaminobenzidine tetrahydrochloride $(0.2 \mathrm{mg} / \mathrm{ml})$ in Tris- $\mathrm{HCl}$ buffer. The reaction was performed with a $1 \mathrm{~h}$ preincubation with $1 \% \mathrm{DMSO}$, then with $\mathrm{H}_{2} \mathrm{O}_{2}$ for $5 \mathrm{~min}$ at room temperature. The sections were washed in PBS and treated with $2 \%$ osmium tetroxide in PBS for $60 \mathrm{~min}$. They were again washed in PBS, followed by ethanol dehydration and embedding in Epok 812 resin (Ouken Shoji, Co. Ltd., Tokyo, Japan). Ultrathin sections were prepared and examined with an electron microscope (1200EX; JEOL Ltd., Tokyo, Japan).

Preparation of labeled RNA probe. A Bam HI/Sau 3A fragment of $\sim 0.5 \mathrm{kbp}$ of the human perforin gene (22) was subcloned into the Bam HI site of pBluescript SK $(+)$ vector (Stratagene Inc., La Jolla, CA). After linearization of the plasmid with appropriate restriction enzymes, ${ }^{35} \mathrm{~S}$-labeled antisense and sense RNA probes were synthesized by T7 or T3 RNA polymerase with ${ }^{35}$ S-UTP and an unlabeled mixture of ATP, GTP, and CTP.

In situ hybridization. Cryostat sections ( $6 \mu \mathrm{m}$ thick) of freshly dissected aortic tissue samples were prepared on slides, which had been pretreated in $3 \times$ SSC $(1 \times$ SSC; $0.15 \mathrm{M}$ sodium chloride and $0.015 \mathrm{M}$ sodium citrate), Denhardt's solution containing $0.02 \%$ Ficoll- 400 , $0.02 \%$ polyvinylpyrrolidone- 360 , and $0.02 \% \mathrm{BSA}$, air dried, and fixed in 4\% paraformaldehyde in PBS for $15 \mathrm{~min}$ at room temperature. After washing in PBS, the sections were dehydrated in ethanol and stored at $-20^{\circ} \mathrm{C}$ until use. The sections were washed three times in $2 \times$ SSC for $15 \mathrm{~min}$, incubated in $0.1 \mathrm{M}$ glycine and $0.1 \mathrm{M}$ Tris- $\mathrm{HCl}(\mathrm{pH} \mathrm{7.0)}$ ) for 30 min at room temperature, and washed in $2 \times \mathrm{SSC}$ for $15 \mathrm{~min}$. Prehybridization was carried out overnight at $50^{\circ} \mathrm{C}$ in a solution containing $50 \%$ deionized formamide, $2 \times \mathrm{SSC}, 0.05 \mathrm{M} 2$-mercaptoethanol, $1 \mathrm{mg} / \mathrm{ml}$ of transfer RNA, $2 \mathrm{mg} / \mathrm{ml}$ of methylated BSA, and $1 \mathrm{mg} / \mathrm{ml}$ of denatured salmon sperm DNA. The serial sections were hybridized with ${ }^{35} \mathrm{~S}$-la- 

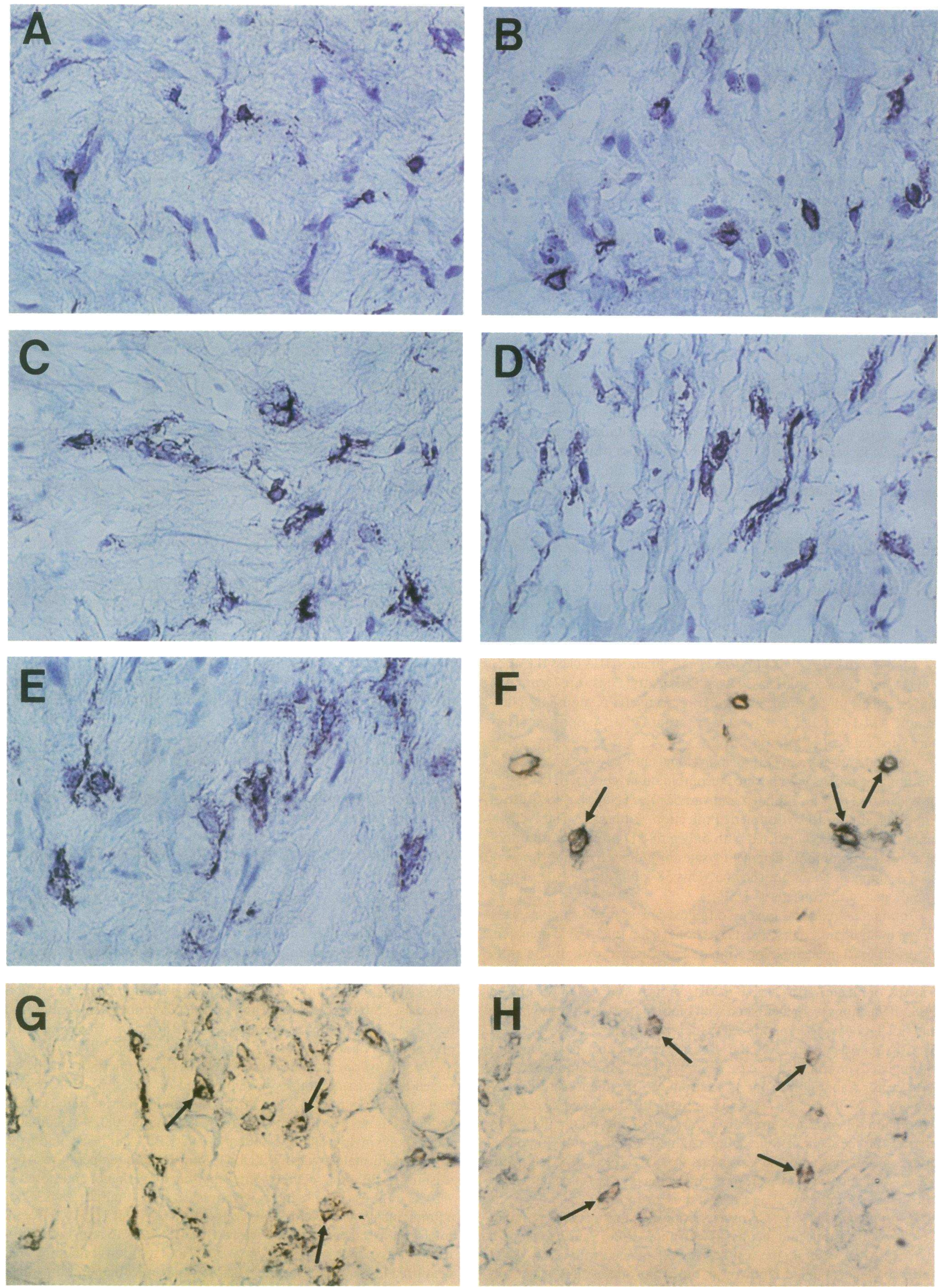

Figure 1. Aortic tissue from a patient with Takayasu's arteritis. $(A-E)$ Phenotypic analysis of infiltrating cells. Aortic tissue sections were stained with anti-CD4 $(A)$, anti-CD8 $(B)$, anti-CD14 $(C)$, anti-CD16 $(D)$, and anti-TCR $\gamma \delta(E)$ mAb. $(F-H)$ Double staining by enzyme antibody method for perforin (blue color, arrows) and surface markers (brown color); CD8 $(F), \operatorname{CD} 16(G)$, and TCR $\gamma \delta(H)$, respectively. $\times 200$. 
Table I. Relative Distribution of Phenotypic Markers among Infiltrating Cells in Aortic Tissue with Takayasu's Arteritis

\begin{tabular}{|c|c|c|c|c|c|c|c|}
\hline \multirow{2}{*}{$\begin{array}{l}\text { Patient } \\
\text { no. }\end{array}$} & \multirow[b]{2}{*}{ Age } & \multirow[b]{2}{*}{ Sex } & \multicolumn{5}{|c|}{ Percentage of cells positive for: } \\
\hline & & & CD4 & CD8 & CD14 & CD16 & $\mathrm{TCR} \gamma \delta$ \\
\hline & $y r$ & & & & & & \\
\hline 1 & 63 & $\mathrm{~F}$ & 15.0 & 13.8 & 11.5 & 8.5 & 30.0 \\
\hline 2 & 29 & $\mathbf{M}$ & 13.3 & 12.0 & 24.5 & 10.8 & 31.5 \\
\hline 3 & 49 & $\mathbf{F}$ & 10.8 & 19.3 & 5.3 & 12.2 & 51.1 \\
\hline 4 & 29 & $\mathbf{M}$ & 14.1 & 13.4 & 13.8 & 16.0 & 35.0 \\
\hline 5 & 50 & $\mathbf{M}$ & 13.8 & 20.3 & 12.5 & 22.5 & 25.5 \\
\hline 6 & 23 & $\mathbf{F}$ & 18.1 & 6.8 & 19.8 & 40.7 & 9.0 \\
\hline 7 & 50 & $\mathrm{~F}$ & 13.5 & 23.5 & 1.3 & 26.5 & 32.0 \\
\hline Mean \pm SE & $41.86 \pm 5.18$ & & $14.09 \pm 0.77$ & $14.84 \pm 1.54$ & $12.67 \pm 2.77$ & $19.60 \pm 3.96$ & $30.59 \pm 4.37$ \\
\hline
\end{tabular}

400 cells were counted for each marker.

beled antisense or sense human perforin RNA probe in the same solution overnight at $50^{\circ} \mathrm{C}$, washed six times in $50 \%$ formamide and $2 \times$ $\mathrm{SSC}$ for $3 \mathrm{~h}$ at $50^{\circ} \mathrm{C}$, and twice in $2 \times \mathrm{SSC}$ for $1 \mathrm{~h}$ at room temperature. Then, they were dipped into NTB-2 nuclear track emulsion (Eastman Kodak, Rochester, NY), which was diluted 1:2 with $6 \mathrm{M}$ ammonium acetate. After exposure for $4 \mathrm{~d}$ at $4^{\circ} \mathrm{C}$, the sections were developed and fixed with Kodak GBK developer and fixer, then counterstained with hematoxilin, dehydrated in ethanol, and coverslips were mounted in xylene with resin.

\section{Results}

Histological examination showed marked thickening of the intima and adventitia, irregular disruption of the medial elastic fibers, and inflammatory cell infiltration involving the vasa vasorum of the media and the adventitia. Along with clinical features, angiography, and blood analyses, a diagnosis of Takayasu's arteritis was established in all seven patients.

Phenotypic analysis of the infiltrating cells. First, we analyzed the phenotypes of the infiltrating cells in aortic tissue with Takayasu's arteritis by immunoperoxidase. As shown in Fig. 1 $(A-E)$, most of the infiltrating cells consisted of $\mathrm{CD} 4^{+} \mathrm{T}$ helper cells (Fig. $1 A$ ), $\mathrm{CD}^{+} \mathrm{CTLs}$ (Fig. $1 \mathrm{~B}$ ), $\mathrm{CD}^{+} 4^{+}$macrophages (Fig. $1 C$ ), CD16 ${ }^{+}$NK cells (Fig. $1 D$ ), and TCR $\gamma \delta^{+} \gamma \delta \mathrm{T}$ lymphocytes (Fig. $1 E$ ). B cells positive for CD20 were few in number or absent (data not shown). The relative distribution of phenotypic markers among the infiltrating cells in each patient are summarized in Table I. In general, it is known that most of the peripheral $\alpha \beta$ T lymphocytes bearing TCR $\alpha \beta$ are
$\mathrm{CD}^{+} \mathrm{CD}^{-}$or $\mathrm{CD}^{-}{ }^{-} \mathrm{CD} 8^{+}$, and that most of the peripheral $\gamma \delta \mathrm{T}$ lymphocytes are $\mathrm{CD}^{-}{ }^{-} \mathrm{CD}^{-}{ }^{-}$. Therefore, the infiltrating $T$ lymphocytes in Takayasu's arteritis consisted of almost an equal percentages of $\alpha \beta$ and $\gamma \delta$ T lymphocytes. To compare the role of infiltrating lymphocytes in Takayasu's arteritis with that in ordinary atherosclerosis, we also analyzed the phenotypes of the infiltrating cells in aortic tissue with atherosclerosis. The relative distribution of phenotypic markers among infiltrating cells in each patient are summarized in Table II. There were few $\gamma \delta \mathrm{T}$ lymphocytes or B lymphocytes (data not shown). As compared with Takayasu's arteritis, aortic sections from atherosclerotic patients had a lower percentage of $\mathrm{T}$ helper cells, with a significant increase in macrophages.

Expression of perforin in infiltrating killer lymphocytes. To analyze the pathogenic role these infiltrating cells might play, we examined the expression of perforin in CTLs, NK cells, and $\gamma \delta \mathrm{T}$ lymphocytes. Fig. $1(F-H)$ shows representative sections with double staining of the infiltrating cells for perforin as blue color and cell surface markers (CD8, CD16, and TCR $\delta 1$ ) as brown color. There was clear expression of perforin in the peripheral cytoplasmic granules of CTLs (Fig. $1 F$ ), NK cells (Fig. $1 G$ ), and $\gamma \delta \mathrm{T}$ lymphocytes (Fig. $1 \mathrm{H}$ ), indicating that these cells are activated killer cells.

Visualization of in vivo release of perforin molecules. To investigate whether these killer cells really damage the aortic vascular cells and to clarify the mechanism, we examined the release of perforin molecules from the infiltrating cells by immunoelectron microscopy. Fig. 2 shows that numerous per-

Table II. Relative Distribution of Phenotypic Markers among Infiltrating Cells in Aortic Tissue with Atherosclerosis

\begin{tabular}{|c|c|c|c|c|c|c|c|}
\hline \multirow{2}{*}{$\begin{array}{l}\text { Patient } \\
\text { no. }\end{array}$} & \multirow[b]{2}{*}{ Age } & \multirow[b]{2}{*}{ Sex } & \multicolumn{5}{|c|}{ Percentage of cells positive for: } \\
\hline & & & CD4 & CD8 & $\mathrm{CD} 14$ & CD16 & TCR $\gamma \delta$ \\
\hline & $y r$ & & & & & & \\
\hline 1 & 76 & $F$ & 1.8 & 16.8 & 21.3 & 19.0 & 0.5 \\
\hline 2 & 68 & $\mathbf{M}$ & 1.3 & 8.5 & 29.5 & 43.3 & 0.5 \\
\hline 3 & 67 & $\mathbf{M}$ & 14.5 & 8.2 & 31.1 & 23.8 & 0.0 \\
\hline 4 & 66 & $\mathbf{M}$ & 7.0 & 13.5 & 41.5 & 29.5 & 1.0 \\
\hline Mean \pm SE & $69.25 \pm 1.98$ & & $6.15 \pm 2.66$ & $11.75 \pm 1.80$ & $30.85 \pm 3.59$ & $28.81 \pm 4.87$ & $0.50 \pm 0.18$ \\
\hline
\end{tabular}

400 cells were counted for each marker. 


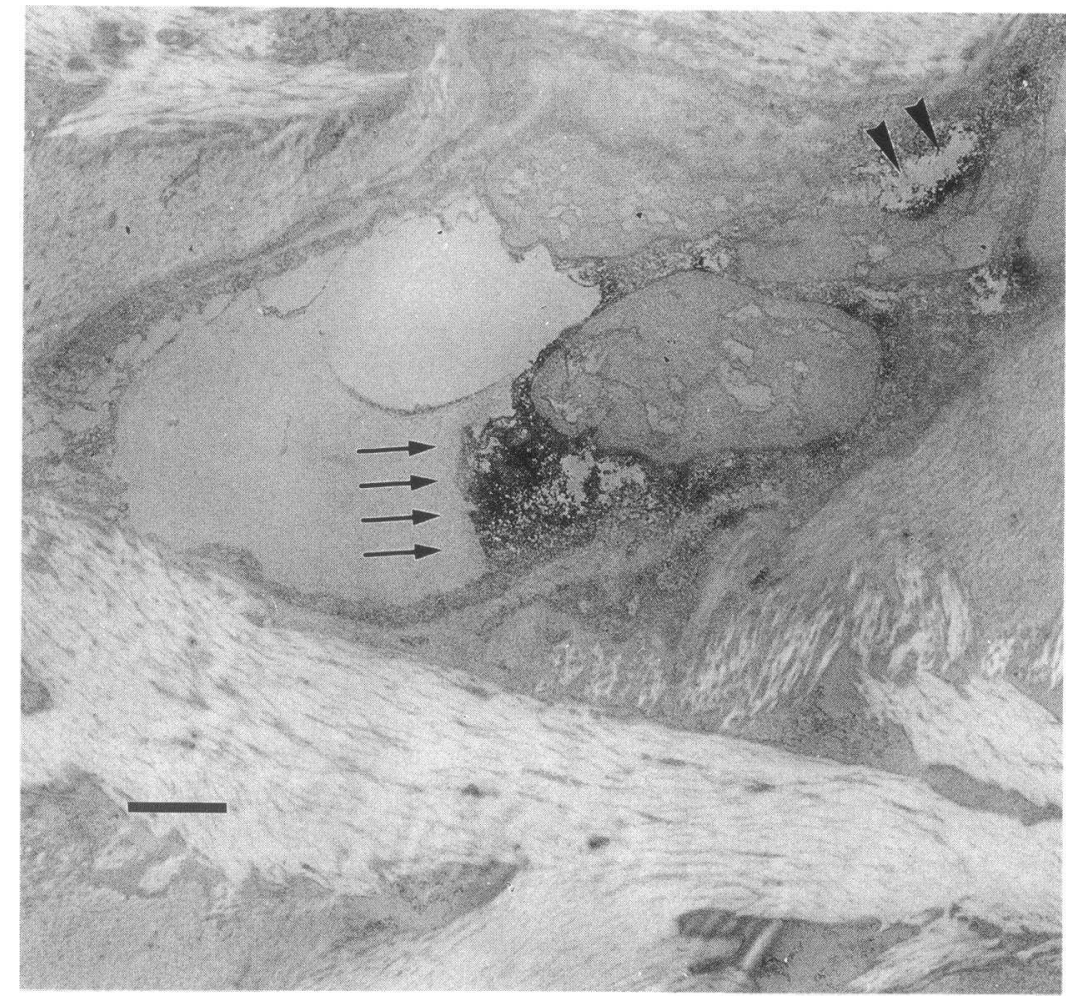

Figure 2. Electron photomicrograph of aortic tissue from a patient with Takayasu's arteritis stained for perforin by immunoperoxidase. Numerous perforin molecules are secreted from an infiltrating cell directly to a vascular cell (arrows). Another infiltrating cell expresses perforin in the peripheral cytoplasm (arrowheads). Bar, $2 \mu \mathrm{m}$. forin molecules are released from the surface of an infiltrating cell and directly onto the surface of an aortic vascular cell, which is in contact with the infiltrating cell (Fig. 2, arrows). This may represent the delivery of a lethal hit and strongly suggests that perforin-mediated direct target cell damage may occur. Although such fields were rather difficult to find, we could find the same fields in several other sections. It is clear that perforin molecules are secreted from the infiltrating cells and pass across the narrow extracellular space $(\sim 3 \mu \mathrm{m})$, as shown in Fig. 2, to reach the surface of the vascular cell. Thus, these data strongly suggest that perforin attacks target cells by passing through the extracellular space, followed by insertion and polymerization in the planar lipid bilayer of the target membrane, rather than by direct insertion into a target membrane in tight contact with the surface of a killer cell. Perforin was also clearly expressed in the peripheral cytoplasm or at the surface of another infiltrating cell (Fig. 2, arrowheads).

Detection of perforin $M R N A$ in the infiltrating cells by in situ hybridization. To confirm the expression of perforin at the transcriptional level, we analyzed the expression of perforin mRNA by in situ hybridization using ${ }^{35} \mathrm{~S}$-labeled antisense and sense RNA probes. Fig. 3 shows one of the representative results of in situ hybridization of serial sections of the aortic tissue samples with antisense (Fig. $3 A$ ) or sense (Fig. $3 B$ ) RNA probes. Strong signals of perforin gene transcripts were found on several infiltrating cells (Fig. $3 \mathrm{~A}$, arrows). Hybridization with the sense RNA probe as a negative control revealed no significant level of signals (Fig. $3 B$ ), showing that the nonspecific background was low.

Expression of HLA class I, class II, and ICAM-1 in the aortic tissue. Fig. 4 shows the expression of HLA classes I and II and ICAM-1 in the vasa vasorum of aortic tissue from normal subjects (Fig. 4, $A-C$ ), and from patients with Takayasu's arteritis (Fig. $4, D-F$ ). In aortic tissue from normal subjects,
HLA class I was moderately expressed in some parts of the intima, adventitia, and vasa vasorum (Fig. $4 \mathrm{~A}$ ), and weakly expressed in the media. HLA class II was moderately expressed in some parts of the intima and the adventitia, and weakly to moderately expressed in the vasa vasorum (Fig. $4 B$ ). ICAM-1 was expressed moderately in some parts of the intima, but only weakly expressed in the vasa vasorum (Fig. $4 C$ ). In patients with Takayasu's arteritis, the expression of these antigens was clearly increased over the aortic tissue. Especially in the vasa vasorum, the expression of HLA class I was markedly increased (Fig. $4 D$ ), and the expression of HLA class II and ICAM-1 was moderately increased (Fig. $4, E$ and $F$, respectively). These findings were representative of the entire samples studied.

Expression of HSP-65 in the aortic tissue. To clarify the mechanism of $\gamma \delta \mathrm{T}$ lymphocyte infiltration, we examined the expression of HSP-65 in aortic tissue with Takayasu's arteritis. Fig. 5 shows the expression of HSP-65 in aortic tissue from normal subjects (Fig. $5 A$ ) and from patients with Takayasu's arteritis (Fig. 5, $B$ and $C$ ). HSP-65 was expressed weakly only in the media of aortic tissue from normal subjects (Fig. $5 \mathrm{~A}$ ). In aortic tissue from patients with Takayasu's arteritis, the expression of HSP-65 was markedly increased in the media (Fig. 5 $B)$. Some of the vasa vasorum also strongly expressed HSP-65 (Fig. 5 C). The enhanced expression of HSP-65 was found in all seven patients with Takayasu's arteritis. There was only weak or slightly increased expression of HSP-65 in the media and the vasa vasorum of aortic tissue with atherosclerotic changes (data not shown).

\section{Discussion}

Not only the etiology of Takayasu's arteritis, but also the mechanism of the vascular cell injury, has been unclear. Although 

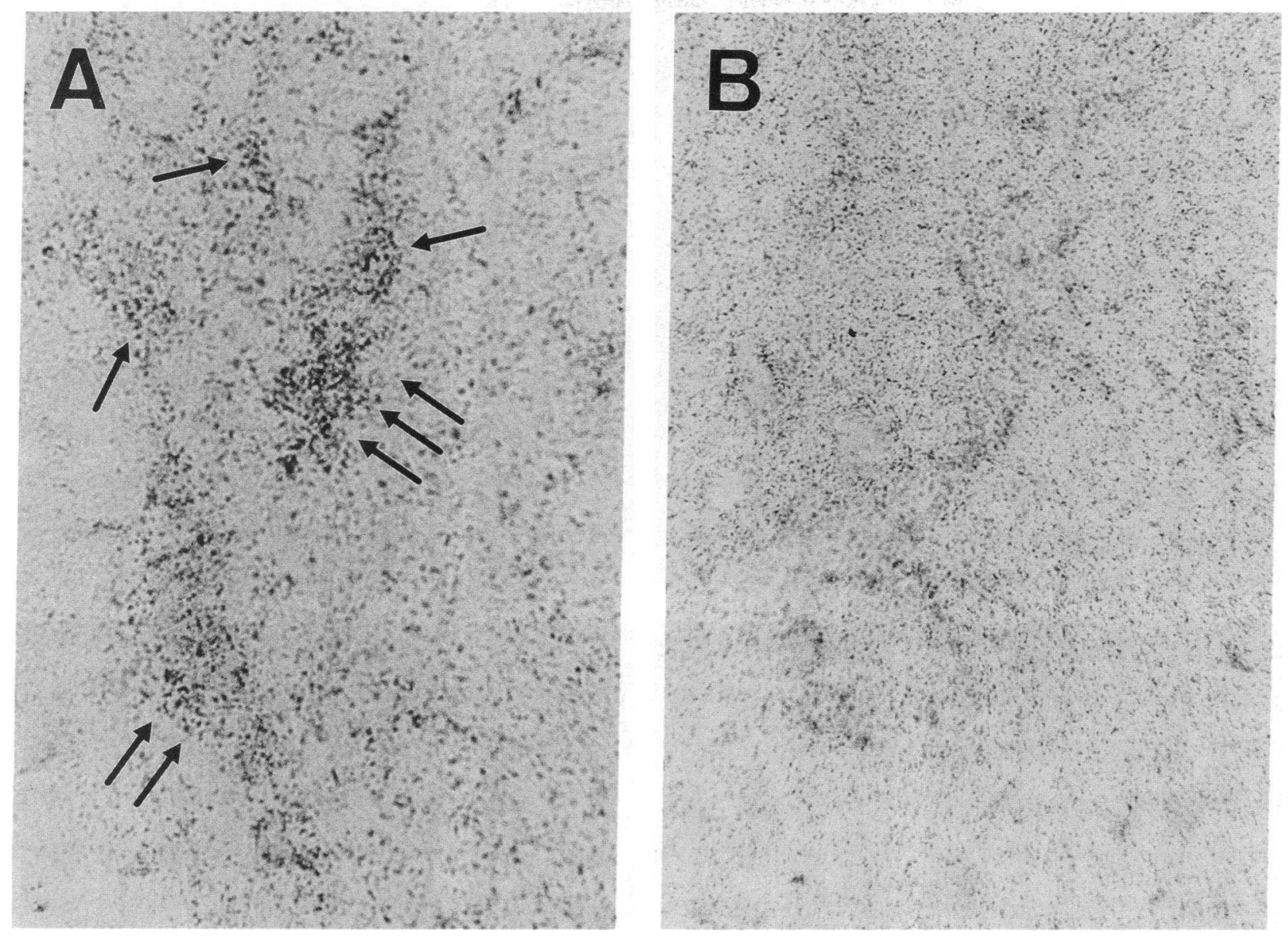

Figure 3. Detection of perforin mRNA in infiltrating cells by in situ hybridization. Serial sections of aortic tissue from a patient with Takayasu's arteritis were hybridized with ${ }^{35}$ S-labeled antisense $(A)$ or sense $(B)$ perforin RNA probe. Several infiltrating cells express perforin mRNA $(A$, arrows). $\times 400$.

circulating autoantibodies such as Coom's antibodies (23) or anticardiolipin antibodies (24), as well as antiaortic antibodies have been reported, there is no evidence that these autoantibodies play a primary role in the immunopathology of Takayasu's arteritis. In the present study, we demonstrated that the infiltrating cells in the aortic tissue with Takayasu's arteritis were perforin-expressing killer cells and directly injure the vascular cells by secreting numerous perforin molecules. This provides direct evidence that cell-mediated cytotoxicity plays a critical role in the vascular cell injury involved in Takayasu's arteritis.

Furthermore, phenotypic analysis showed that $\sim 30 \%$ of the infiltrating cells consisted of $\gamma \delta \mathrm{T}$ lymphocytes in Takayasu's arteritis, whereas there was virtually no infiltration of $\gamma \delta \mathrm{T}$ lymphocytes in the aortic tissue of patients with atherosclerosis. This may indicate that quite different immunological mechanisms are involved in the pathogenesis of Takayasu's arteritis compared with atherosclerosis. We found that HSP65 , to which $\gamma \delta \mathrm{T}$ lymphocytes were shown to respond (18, 19 ), was strongly induced in the media and vasa vasorum, supporting the participation of $\gamma \delta \mathrm{T}$ lymphocytes in Takayasu's arteritis. In contrast, there was only weak or slightly increased expression of HSP-65 in ordinary artherosclerotic lesions (data not shown), consistent with the absence of $\gamma \delta \mathrm{T}$ lymphocytes. Xu et al. (25) reported that immunization with HSP-65 induced arteriosclerotic lesions in normocholesterole- mic rabbits. Recently, the authors reported that serum antiHSP-65 antibodies were significantly increased in patients with carotid atherosclerosis (26). However, there was no evidence that dominant population of the infiltrating $\mathrm{T}$ cells bear TCR $\gamma \delta$ and that HSP-65 is strongly induced in the arteriosclerotic lesions. It is uncertain that HSP-65-induced arteriosclerotic lesions can be a model for human atherosclerosis. Hohlfeld et al. (27) reported a case of polymyositis highly responsive to steroid therapy that was mainly mediated by $\gamma \delta \mathrm{T}$ lymphocytes. The authors demonstrated that all muscle fibers strongly expressed HSP-65, as well as HLA class I. Therefore, the high responsiveness to steroid therapy also support the critical role of $\gamma \delta$ T lymphocytes in the pathogenesis of Takayasu's arteritis.

We also found enhanced expression of HLA classes I and II along with ICAM-1 at the site of inflammation, especially in the vasa vasorum. The enhanced expression of these antigens may establish the vascular cells as target cells for NK cells and $\mathrm{T}$ lymphocytes, and may facilitate the cytotoxicity of these killer lymphocytes. It is known that activated T cells and NK cells synthesize cytokines such as IFN- $\gamma$ or TNF- $\alpha$ in high concentration at the site of inflammation. Therefore, we suspected that cytokines, released by the infiltrating cells, might play a major role in inducing the expression of HLAs and ICAM-1 in aortic tissue, especially around the cell infiltration. Our data strongly suggest that the infiltrating $\gamma \delta \mathrm{T}$ lymphocytes may 

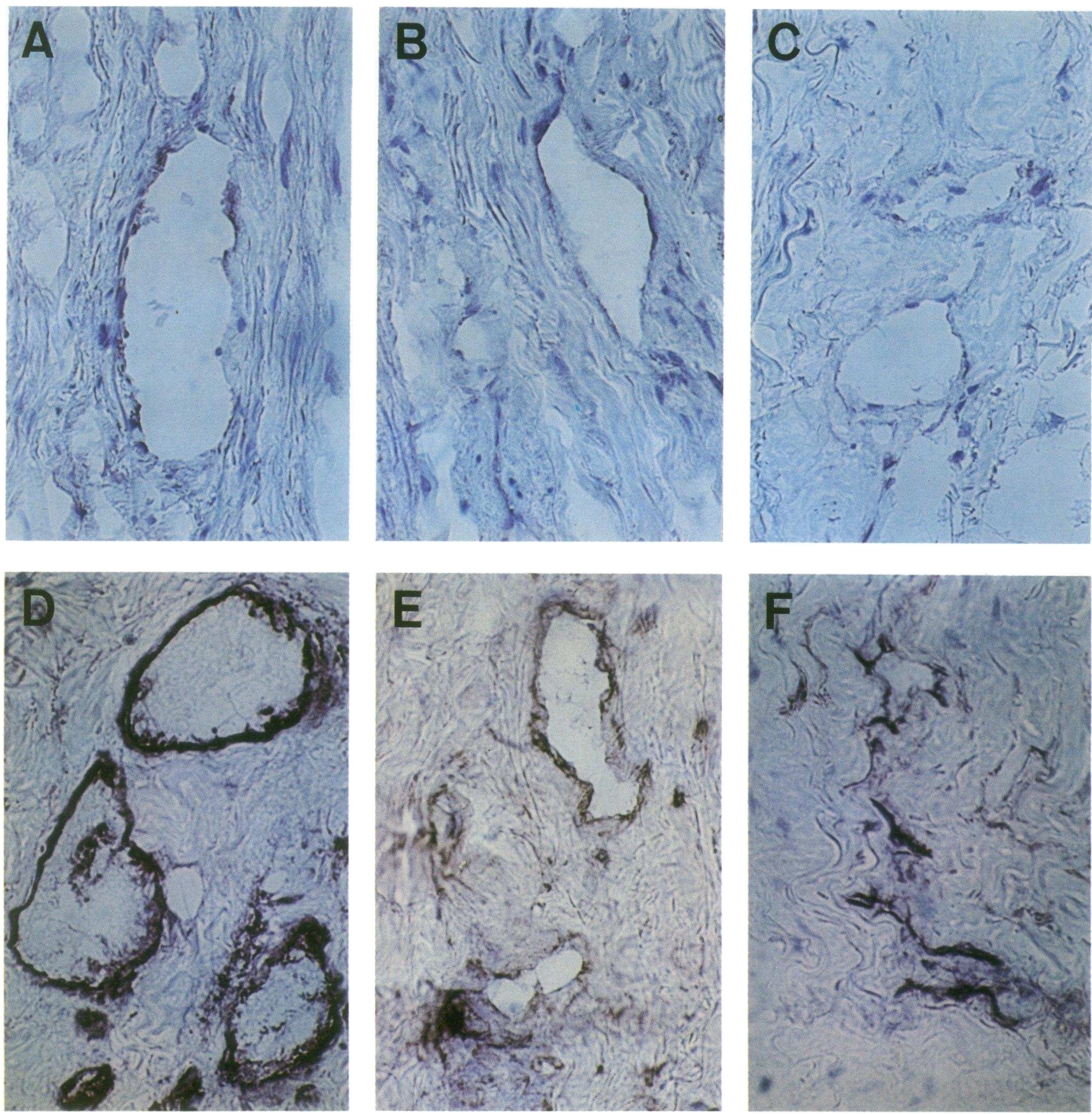

Figure 4. Immunohistochemical study of aortic tissue for HLA classes I and II, and ICAM-1. $(A-C)$ Aortic tissue from a normal subject stained with anti-HLA classes I and II, and ICAM-1, respectively. ( $D-F)$ Aortic tissue from a patient with Takayasu's arteritis stained with anti-HLA classes I and II, and ICAM-1, respectively. Note that the expression of these antigens were moderately to markedly increased in the vasa vasorum of aortic tissue from a patient with Takayasu's arteritis. $\times 200$.

play, at least in part, an important role in the vascular cell injury, and that expression of HSP-65 and HLAs in vascular cells may facilitate the recognition and cytotoxicity of the $\gamma \delta \mathrm{T}$ lymphocytes. Results of other studies of peripheral blood (11) and of autoimmune diseases (12) support a cytotoxic role for $\gamma \delta$ T lymphocytes.

Evidence has accumulated that perforin is released from the cytoplasmic granules of killer cells during target cell lysis, followed by its insertion and polymerization on the target membrane to form transmembrane tubular lesions (perforin pores), which in turn cause colloid-osmotic injury to the target cells $(5,28,29)$. However, these studies were performed in vitro, and there has been no evidence showing the granule exo- cytosis mechanism of perforin in cell-mediated cytotoxicity primed in vivo. We previously reported that NK cells, which express perforin, infiltrate murine hearts affected by acute viral myocarditis (8). Recently, using the same model of viral myocarditis, we have demonstrated by immunoelectron microscopy that numerous perforin molecules are released from the infiltrating cells directly onto the surface of cardiac myocytes, and that there are many circular lesions characteristic of perforin pores on the membrane of cardiac myocytes (30). The results in the present study strongly suggest that the infiltrating killer cells directly injure the vascular cells in Takayasu's arteritis by the same mechanism as noted in viral myocarditis.

Although the nature of the antigen that triggers the autoim- 

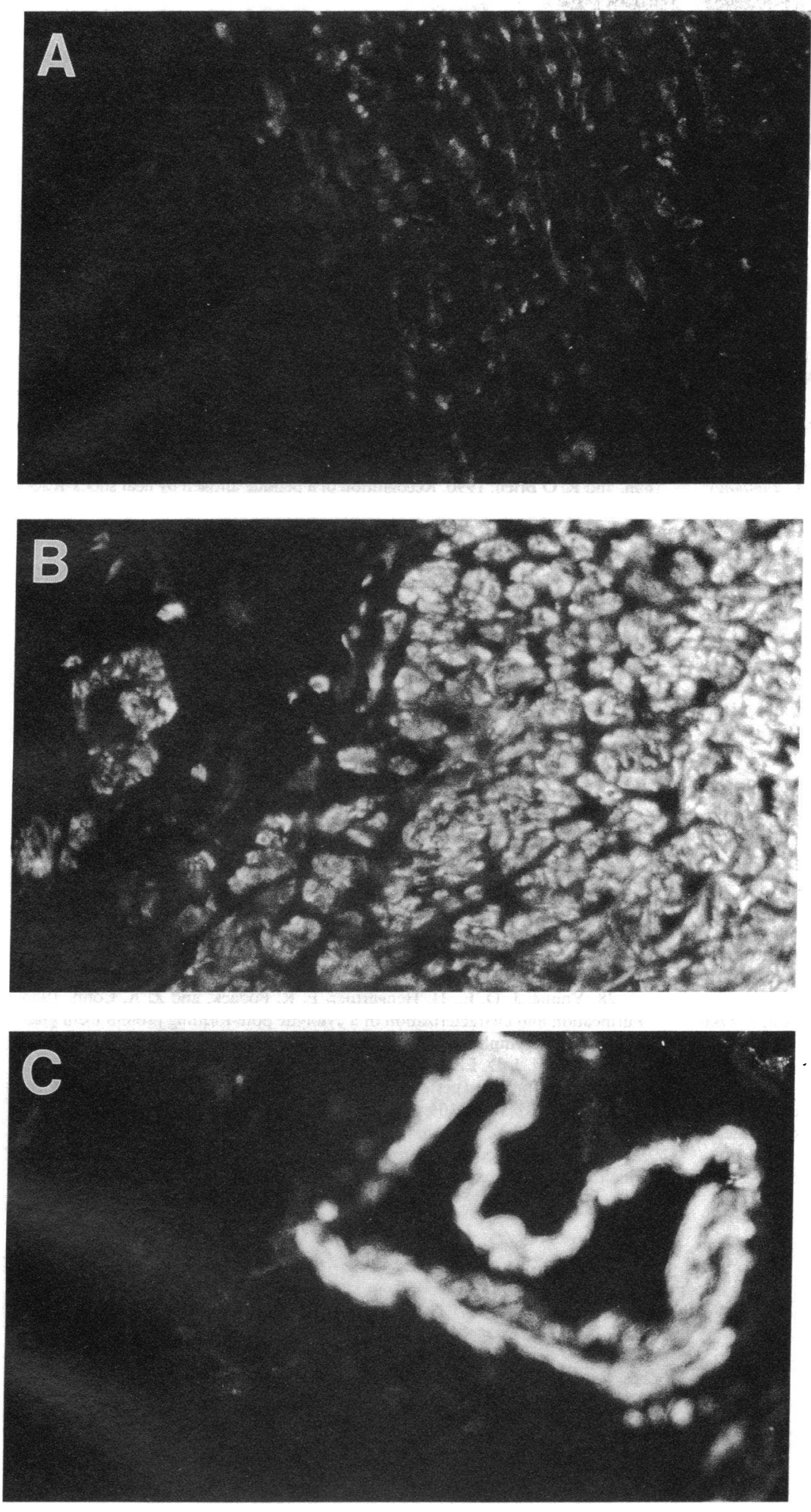

Figure 5. Immunofluorescence study of aortic tissue for HSP-65. ( $A$ ) Aortic tissue from normal subject. $(B$ and $C)$ Aortic tissue from a patient with Takayasu's arteritis. Note that the expression of HSP65 was markedly increased in the media $(B)$ and in some of the vasa vasorum $(C)$ in Takayasu's arteritis. $\times 200$.

mune process involved in Takayasu's arteritis is unknown, it is thought that the infiltrating $\mathrm{T}$ perforin may recognize some antigen, either in the form of a small, processed protein fragment or as a superantigen, in association with HLAs. It is also unclear whether or not the antigen recognized by infiltrating $\gamma \delta$ $T$ lymphocytes is the same as that recognized by infiltrating $\alpha \beta$ $T$ lymphocytes. To investigate the antigen specificity of the infiltrating $\mathrm{T}$ lymphocytes, we are currently analyzing the extent of TCR ( $\gamma \delta$ as well as $\alpha \beta$ ) variable region gene usage by the polymerase chain reaction. Our data support the previous reports that the specificity of HLA antigens, which play an important role in the recognition of antigens by $\mathrm{T}$ lymphocytes, are associated with Takayasu's arteritis and may determine susceptibility to the disease. 


\section{Acknowledgments}

We thank Mr. M. Sakamoto, Institute for Adult Diseases, Asahi Life Foundation, for technical assistance with electron microscopy.

This work was supported by grants for Intractable Vasculitis and for cardiomyopathy from the Ministry of Health and Welfare, Japan, a grant from Japan Foundation for Health Sciences, and a grant from Japan Intractable Disease Research Foundation.

\section{References}

1. Numano, F., I. Isohisa, U. Kishi, M. Arita, and H. Maezawa. 1978. Takayasu's disease in twin sisters. Possible genetic factors. Circulation. 58:173177

2. Numano, F., I. Isohisa, H., Maezawa, and T. Juji. 1979. HL-A antigens in Takayasu's disease. Am. Heart J. 98:153-159.

3. Takeuchi, Y., K. Matsuki, Y. Saito, T. Sugimoto, and T. Juji. 1990. HLA-D region genomic polymorphism associated with Takayasu's arteritis. Angiology 41:421-426.

4. Scott, D. G. I., M. Salmon, D. L. Scott, A. Blann, P. A. Bacon, K. W. Walton, C. D. H. Oakland, and G. F. Slaney. 1986. Takayasu's arteritis: a pathogenetic role for cytotoxic T lymphocytes? Clin. Rheumatol. 5:517-522.

5. Young, J. D. E. 1989. Killing of target cells by lymphocytes: A mechanistic view. Physiol. Rev. 69:250-314.

6. Young, L. H. Y., L. S. Klavinskis, M. B. A. Oldstone, and J. D. E. Young. 1989. In vivo expression of perforin by $\mathrm{CD}^{+}$lymphocytes during an acute viral infection. J. Exp. Med. 169:2159-2171.

7. Young, L. H. Y., L. B. Peterson, L. S. Wicker, P. M. Persechini, and J. D. E Young. 1989. In vivo expression of perforin by $\mathrm{CD}^{+}$lymphocytes in autoimmune disease: studies on spontaneous and adoptively transferred diabetes in nonobese diabetic mice. J. Immunol. 143:3994-3999.

8. Seko, Y., Y. Shinkai, A. Kawasaki, H. Yagita, K. Okumura, F. Takaku, and Y. Yazaki. 1991. Expression of perforin in infiltrating cells in murine hearts with acute myocarditis caused by coxsackievirus B3. Circulation. 84:788-795.

9. Kawasaki, A., Y. Shinkai, H. Yagita, and K. Okumura. 1992. Expression of perforin in murine natural killer cells and cytotoxic $\mathrm{T}$ lymphocytes in vivo. Eur. J. Immunol. 22:1215-1219.

10. Kawasaki, A., Y. Shinkai, Y. Kuwana, A. Furuya, Y. Iigo, N. Hanai, S Itoh, H. Yagita, and K. Okumura. 1990. Perforin, a pore forming protein detectable by monoclonal antibodies, is a functional marker for killer cells. Int. Im munol. 2:677-684.

11. Nakata, M., M. J. Smyth, Y. Norihisa, A. Kawasaki, Y. Shinkai, K. Okumura, and H. Yagita. 1990. Constitutive expression of pore-forming protein in peripheral blood $\gamma / \delta \mathrm{T}$ cells: implication for their cytotoxic role in vivo. J. Exp. Med. 172:1877-1880.

12. Koizumi, H., C. C. Liu, L. M. Zheng, S. V. Joag, N. K. Bayne, J. Holoshitz, and J. D. E. Young. 1991. Expression of perforin and serine esterases by human $\gamma / \delta$ T cells. J. Exp. Med. 173:499-502.

13. Marlin, S. D., and T. A. Springer. 1987. Purified intercellular adhesion molecule-1 (ICAM-1) is a ligand for lymphocyte function-associated antigen 1(LFA-1). Cell. 51:813-819.

14. Krensky, A. M., E. Robbins, T. A. Springer, and S. J. Burakoff. 1984 LFA-1, LFA-2 and LFA-3 antigens are involved in CTL-target conjunction. $J$. Immunol. 132:2180-2182.

15. Dustin, M. L., R. Rothlein, A. K. Bhan, C. A. Dinarello, and T. A Springer. 1986. Induction by IL-1 and interferon, tissue distribution, biochemistry, and function of a natural adherence molecule (ICAM-1). J. Immunol 137:245-254.

16. Rothlein, R., M. Czajkowski, M. M. O'Neill, S. D. Marlin, E. Mainolfi, and V. J. Merluzzi. 1988. Induction of intercellular adhesion molecule 1 on primary and continuous cell lines by pro-inflammatory cytokines: Regulation by pharmacologic agents and neutralizing antibodies. J. Immunol. 141:1665-1669.

17. Dustin, M. L., K. H. Singer, D. T. Tuck, and T. A. Springer. 1988. Adhesion of $\mathrm{T}$ lymphoblasts to epidermal keratinocytes is regulated by interferon $\gamma$ and is mediated by intercellular adhesion molecule 1 (ICAM-1). J. Exp. Med. 167:1323-1340.

18. Haregewoin, A., G. Soman, R. C. Hom, and R. W. Finberg. 1989. Human $\gamma \delta^{+} \mathrm{T}$ cells respond to mycobacterial heat-shock protein. Nature (Lond.) 340:309-312.

19. Born, W., L. Hall, A. Dallas, J. Boymel, T. Shinnick, D. Young, P. Brennan, and R. O'Brien. 1990. Recognition of a peptide antigen by heat shock-reactive $\gamma \delta$ T lymphocytes. Science (Wash. DC). 249:67-69.

20. Shinkai, Y., K. Takio, and K. Okumura. 1988. Homology of perforin to the ninth component of complement (C9). Nature (Lond.). 334:525-527.

21. Yagita, H., M. Nakata, A. Kawasaki, Y. Shinkai, and K. Okumura. 1992. Role of perforin in lymphocyte-mediated cytolysis. Adv. Immunol. 51:215-242.

22. Shinkai, Y., M. C. Yoshida, K. Maeda, T. Kobata, K. Maruyama, J. Yodoi, H. Yagita, and K. Okumura. 1989. Molecular cloning and chromosomal assignment of a human perforin (PFP) gene. Immunogenetics. 30:452-457.

23. Kanzaki, S., and S. Kanda. 1985. Cooms' antibodies and rheumatoid factors in Takayasu's arteritis. J. Am. Med. Assoc. 254:232-232.

24. Mchugh, N. J., I. E. James, and G. T. Plant. 1990. Anticardiolipin and antineutrophil antibodies in giant cell arteritis. J. Rheumatol. 17:916-922.

25. Xu, Q., H. Dietrich, H. J. Steiner, A. M. Gown, B. Schoel, G. Mikuz, S. H. E. Kaufmann, and G. Wick. 1992. Induction of arteriosclerosis in normocholesterolemic rabbits by immunization with heat shock protein 65 . Arterioscler. Thromb. 12:789-799.

26. Xu, Q., J. Willeit, M. Marosi, R. Kleidienst, F. Oberhollenzer, S. Kiechl, T. Stulnig, G. Luef, and G. Wick. 1993. Association of serum antibodies to heat-shock protein 65 with carotid atherosclerosis. Lancet. 341:255-259.

27. Hohlfeld, R., A. G. Engel, K. Ii, and M. C. Harper. 1991. Polymyositis mediated by $\mathrm{T}$ lymphocytes that express the $\gamma / \delta$ receptor. $N$. Engl. J. Med. 324:877-881.

28. Young, J. D. E., H. Hengartner, E. R. Podack, and Z. A. Cohn. 1986. Purification and characterization of a cytolytic pore-forming protein from granules of cloned lymphocytes with natural killer activity. Cell. 44:849-859.

29. Young, J. D. E., E. R. Podack, and Z. A. Cohn. Properties of a purified pore-forming protein (perforin 1 ) isolated from $\mathrm{H}$-2-restricted cytotoxic $\mathrm{T}$ cell granules. J. Exp. Med. 164:144-155.

30. Seko, Y., Y. Shinkai, A. Kawasaki, H. Yagita, K. Okumura, and Y. Yazaki. 1993. Evidence of perforin-mediated cardiac myocyte injury in acute murine myocarditis caused by coxsackievirus B3. J. Pathol. 170:53-58. 